\title{
MANAJEMEN TEAM TEACHING MATA PELAJARAN KEJURUAN DI SMKN 1 GOMBONG DAN SMKN 1 PURING
}

\author{
Esti Retnoningsih, Zainal Arifin \\ SMKN 2 Kebumen \\ Email: fulanah_85@yahoo.com
}

\begin{abstract}
Abstrak
Penelitian ini bertujuan untuk mengetahui; (1) informasi empirik pelaksanaan Team Teaching, dan implementasi manajemen Team Teaching, (2) proses evaluasi pelaksanaan Team Teaching yang ada di SMKN 1 Gombong dan SMKN 1 Puring. Penelitian ini menggunakan pendekatan kualitatif dengan jenis penelitian deskriptif kualitatif. Pengumpulan data dilakukan menggunakan wawancara, dokumentasi, dan observasi. Teknik analisis data yang digunakan adalah analisis data induktif. Hasil penelitian menunjukkan bahwa (1) program keahlian Teknik Kendaraan di SMK N 1 Gombong melaksanakan pembelajaran team teaching; sedangkan di SMKN 1 Puring penerapan pembelajaran team teaching belum sepenuhnya melaksanakan prinsip pembelajaran bertim, (2) implementasi manajemen team teaching di SMK N 1 Gombong sudah berjalan cukup baik; sementara itu implementasi manajemen team teaching di SMKN 1 Puring masih memerlukan beberapa perbaikan pada masing-masing unsur manajemen, (3) team teaching di SMKN 1 Gombong secara umum telah berjalan baik dengan terpenuhinya prinsip pembelajaran bertim dan prinsip manajemen; team teaching di SMKN 1 Puring secara umum membutuhkan perbaikan sehingga dapat memenuhi prinsip pembelajaran bertim dan manajemen yang baik.
\end{abstract}

Kata kunci: team teaching, manajemen, program keahlian Teknik Kendaraan Ringan

\section{TEAM TEACHING MANAGEMENT ON VOCATIONAL SUBJECT IN SMKN 1 GOMBONG AND SMKN 1 PURING}

\begin{abstract}
The objective of this research is to determine; (1) empiric information of team teaching implementation, and management team teaching implementation, (2) the evaluation process of team teaching implementation at SMKN 1 Gombong and SMKN 1 Puring. This research used qualitative approach. Data were collected by interview, documentation, and observation. Data analysis technique used inductive analysis data. The results of the research indicate that (1) Otomotif Department of SMKN 1 Gombong applied team teaching learning model; while team teaching in SMKN 1 Puring did not apply the full principles of team teaching learning model, (2) Management team teaching implementation in SMKN 1 Gombong was done effectively enough; besides management team teaching implementation in SMKN 1 Puring needs some improvements for each part of management process (3) Team teaching in SMKN 1 Gombong relatively fulfilled the principles of team teaching learning models and management process; while team teaching in SMKN 1 Puring needed some improvents to fullfill principles of team teaching model and management process.
\end{abstract}

Keywords: team teaching, management, Otomotive Department 


\section{PENDAHULUAN}

Kurikulum pendidikan pada tingkat SMK (Sekolah Menengah Kejuruan), dibagi ke dalam tiga kelompok besar program pelatihan, yaitu; Normatif yang berkaitan dengan pembentukan watak, Adaptif berkaitan dengan penanaman dasar dan pengembangan kemampuan profesi, serta Produktif yang berkaitan dengan pembekalan ketrampilan produktif sesuai program keahlian yang dipilih yang nantinya bermanfaat bagi penerapan pada pekerjaan di dunia industri.

Terdapat perbedaan kebijakan pelaksanaan proses pembelajaran antara guru normatif adaptif dengan guru mata pelajaran kejuruan di tingkat Sekolah Menengah Kejuruan. Pada mata pelajaran Normatif dan Adaptif, satu rombongan belajar (kelas) diampu oleh satu orang guru pada tiap mata pelajaran. Untuk mata pelajaran kejuruan, satu rombongan belajar diampu oleh dua guru untuk pelajaran teori. Sementara untuk pelajaran praktik pada mata pelajaran kejuruan, satu rombongan belajar diampu oleh minimal 2 orang guru. Pada mata pelajaran kejuruan di SMK, satu mata pelajaran kejuruan memiliki jam pelajaran yang cukup banyak. Satu mata pelajaran kejuruan terdiri dari 8 jam pelajaran. Sementara itu, pada satu tingkat terdapat rata-rata 3 mata pelajaran kejuruan. Dengan demikian, dalam satu minggunya, pada satu rombongan belajar (kelas) terdapat minimal 24 jam pelajaran untuk kejuruan.

Dengan jumlah jam pelajaran yang cukup banyak, dan beban mengajar yang berbeda dengan mata pelajaran normatif dan adaptif, maka dilaksanakan kebijakan Team Teaching pada mata pelajaran Kejuruan di SMK. Kebijakan ini diharapkan akan mampu menghasilkan pembelajaran efektif dan hasil pembelajaran yang optimal terutama pada mata pelajaran praktik kejuruan. Dengan jumlah siswa rata-rata 32 siswa tiap rombongan belajar, tentunya dibutuhkan guru dengan jumlah lebih dari satu untuk dapat membimbing siswa dengan optimal pada saat pelaksanaan praktik kejuruan di bengkel. Jumlah siswa 32 ini berdasarkan pada permendiknas no.41 tahun 2007 tentang standar proses yang menyatakan bahwa syarat pelaksanaan proses pembelajaran adalah bahwa; (1) Satu rombel pada SMK/MAK terdiri dari 32 peserta didik. (2) Beban kerja minimal guru adalah 24 jam tatap muka dalam satu minggu.

Jurnal of Adult Education (Laughlin, Nelson, dan Donaldson, 2011:1) menjabarkan tentang team teaching sebagai sebuah strategi besar untuk menjalankan sistem berpikir siswa, keluarga, dan masyarakat untuk membantu pembelajar menggali berbagai sudut pandang. Peserta dapat menggali berbagai pengetahuan dari instruktur instruktur yang terampil. Dengan demikian, team teaching ini sesungguhnya memiliki peran yang cukup signifikan dalam pencapaian prestasi belajar dan penguasaan kompetensi keahlian pada mata pelajaran teori kejuruan dan Praktik Kejuruan pada program keahlian Teknik Kendaraan Ringan. Melalui tim ini, siswa akan memperoleh kompetensi keahlian yang maksimal.

Terkait team teaching itu sendiri, terdapat enam model pembelajaran team teaching yaitu: (1) Team Teaching (traditional team teaching). (2) One Teach, One Observe. (3) Station Teaching. (4) Parallel Teaching. (5) Alternate Teaching. (6) One Teach, One Assist (Marilyn, Alvis, dan Marilyn, 2005). Pelaksanaan team teaching ini sebenarnya akan menjadi efektif dalam mencapai hasil output siswa yang memiliki kapasitas keilmuan dan keahlian yang baik ketika diterapkan secara maksimal. Melalui tim ini, diharapkan satu kompetensi yang diajarkan dan yang menjadi target pembelajaran terutama pada mata pelajaran praktik kejuruan akan diajarkan secara utuh oleh guru-guru yang memiliki kompetensi akademik dan profesional dalam menjalankan tugas dan perannya sebagai guru. Selain itu, siswa akan memperoleh berbagai keuntungan 
sebagaimana dituliskan oleh Brandenburg pada jurnal Succesfully Applying Team Teaching With Adult Learners, yaitu: (1) Team teaching can open a learner's eyes toaccepting more than one opinion and to workingmore cooperatively with others. Team teaching provides educational benefitssuch as increasing the student's level ofunderstanding and retention. (2) Two or more varying views help learners blurthe black-and-white way of thinking common inour society and see many shades of gray. (3) The variety of teaching approaches used by theteam can also reach a greater variety of learning styles (Laughlin, Nelson, dan Donaldson, 2011:4). Akan tetapi, dalam pelaksanaannya di lapangan, belum seluruh tim yang team teaching dalam rangka mencapai tujuan pembelajaran yang efektif. Dari survei awal di beberapa SMK Negeri Program Keahlian Teknik Kendaraan Ringan di Kebumen, diperoleh data bahwa terdapat beberapa penyimpangan dalam pelaksanaan team teaching itu sendiri, ada yang memanfaatkan kebijakan ini untuk kepentingan pribadi melalui kerjasama yang seharusnya tidak dilakukan antar anggota tim. Sebagai contoh, melakukan pergantian jam mengajar dalam membimbing praktik kejuruan yangseharusnya mengajar secara bersama dalam satu waktu, akan tetapi justru bergantian agar waktu yang ada dapat digunakan untuk kepentingan yang lain (pribadi).

Selain hal tersebut, diperoleh data bahwa nilai rata-rata UN untuk Mata pelajaran Kejuruan dari tahun ke tahun cenderung sama, dan belum ada peningkatan yang signifikan. sehingga dibutuhkan sebuah perbaikan maupun peningkatan dalam upaya peningkatan hasil pembelajaran tersebut.

Dari survei awal di beberapa SMK Negeri Program Keahlian Teknik Kendaraan Ringan di Kebumen, diperoleh data bahwa terdapat beberapa penyimpangan dalam pelaksanaan team teaching itu sendiri, ada yang memanfaatkan kebijakan ini untuk kepentingan pribadi melalui kerjasama yang seharusnya tidak dilakukan antar anggota tim. Sebagai contoh, melakukan pergantian jam mengajar dalam membimbing praktik kejuruan yangseharusnya mengajar secara bersama dalam satu waktu, akan tetapi justru bergantian agar waktu yang ada dapat digunakan untuk kepentingan yang lain (pribadi).

Sementara itu, berdasarkan Pedoman Pelaksanaan Tugas Guru dan Pengawas (Depdiknas, 2009), dijelaskan bahwa pembelajaran tim harus memenuhi prinsip - prinsip berikut: (1) Dilaksanakan apabila semua topik/pokok bahasan pada mata pelajaran tertentu memerlukan lebih dari satu orang guru untuk menangani satu rombongan belajar yang proses pembelajarannya merupakan satu kesatuan. (2) Perencanaan dalam pemilihan pokok bahasan dilakukan pada awal tahun ajaran. (3) Pembelajaran bertim dilaksanakan pada tiap minggu. (4) Jumlah guru bertim disesuaikan dengan karakteristik materi pembelajaran. (5) Anggota tim berasal dari guru-guru dari sekolah yang sama. (6) Perencanaan, pelaksanaan dan evaluasi harus dilakukan bersama-sama oleh anggota tim. (7) Setiap guru dalam pembelajaran bertim memiliki jumlah tatap muka yang sama sesuai dengan struktur kurikulum.

Prinsip tersebut di atas seharusnya dipenuhi oleh seluruh guru dalam proses pelaksanaan pembelajaran team teaching yang dilaksanakan di masing-masing sekolah dan program keahlian pada mata pelajaran teori kejuruan maupun praktik kejuruan.

Dari survei awal di beberapa SMK Negeri Program Keahlian Teknik Kendaraan Ringan di Kebumen, diperoleh data bahwa terdapat beberapa penyimpangan dalam pelaksanaan team teaching itu sendiri, ada yang memanfaatkan kebijakan ini untuk kepentingan pribadi melalui kerjasama yang seharusnya tidak dilakukan antar anggota tim. Sebagai contoh, melakukan 
pergantian jam mengajar dalam membimbing praktik kejuruan yang seharusnya mengajar secara bersama dalam satu waktu, akan tetapi justru bergantian agar waktu yang ada dapat digunakan untuk kepentingan yang lain (pribadi).

Dari berbagai kondisi di atas, penulis tertarik untuk melakukan penelitian terkait; 1) gambaran umum pembelajaran team teaching pada mata pelajaran kejuruan di SMKN 1 Gombong dan SMKN 1 Puring, 2) seperti apa implementasi manajemen team teaching pada mata pelajaran kejuruan di SMKN 1 Gombong dan SMKN 1 Puring, dan 3) sejauh mana proses evaluasi pembelajaran team teaching dilaksanakan di SMKN 1 Gombong dan SMKN 1 Puring.

\section{METODE}

Jenis Penelitian

Penelitian yang dilakukan adalah penelitian deskriptif dengan pendekatan kualitatif. Dengan pendekatan kualitatif ini, diharapkan data yang diperoleh bisa lebih mendalam, natural, kredibel dan bermakna, sehingga tujuan penelitian ini dapat tercapai. Data yang diperoleh merupakan data primer, yang didapatkan langsung dari sumber yang tepat pada lokasi penelitian.

Tempat dan Waktu Penelitian

Terdapat lima SMK Negeri di Kabupaten Kebumen yang memiliki program keahlian Teknik Kendaraan Ringan, yaitu SMKN 2 Kebumen, SMKN 1 Ambal, SMK N 1 Puring, SMKN 1 Karanggayam, SMKN 1 Gombong. Akan tetapi, dari kelima SMK tersebut tidak seluruhnya dijadikan tempat penelitian. Penelitian ini akan dilakukan di SMKN 1 Gombong dan SMKN 1 Puring pada bulan Maret hingga Mei 2014.

\section{Subjek Penelitian}

Pengambilan data dan informasi dalam penelitian ini dilaksanakan secara langsung dari Kepala Sekolah, Ketua Jurusan Teknik Kendaraan Ringan, guru serta siswa Program Teknik Kendaraan Ringan di SMKN 1 Puring dan SMKN 1 Gombong.

Subjek penelitian ini adalah sumber data utama yang relevan dengan penelitian yang dilakukan, sehingga yang dipilih menjadi subjek penelitian adalah: (1) kepala sekolah dari kedua sekolah tersebut sebagai pihak yang bertanggung jawab atas sekolah secara penuh, (2) ketua jurusan Teknik Kendaraan Ringan di kedua sekolah tersebut sebagai pihak yang bertanggung jawab pada masing-masing jurusan, (3) perwakilan 2 guru PNS senior dan 1 orang guru PNS mula di jurusan Teknik Kendaraan Ringan dari masing masing sekolah, 4) dan perwakilan 2 siswa kelas XI dari masing-masing sekolah.

Penentuan subjek penelitian ini berdasarkan pada kebutuhan penelitian, dan dianggap telah memadai apabila telah sampai pada taraf redundancy (datanya telah jenuh). Penentuan subjek penelitian juga mempertimbangkan relevansinya dengan tujuan penelitian. Teknik yang digunakan dalam pemilihan responden adalah purposive sampling.

\section{Teknik Pengumpulan Data}

Penelitian ini menggunakan tiga teknik pengumpulan data tersebut, yaitu: Observasi, atau yang disebut pula dengan pengamatan di dalam pengertian psikologik, meliputi kegiatan pemuatan perhatian terhadap sesuatu objek dengan menggunakan seluruh alat indra. Observasi dilakukan untuk mendapatkan informasi terkait dengan perilaku manusia (guru) dalam menjalankan kegiatan pembelajaran serta proses pembelajaran itu sendiri. Selain itu, observasi ini juga bertujuan untuk memperoleh data pendukung yang tidak diperoleh melalui teknik pengambilan data yang lain.

Dokumentasi, diartikan barangbarang tertulis. Dalam pelaksanaan metode dokumentasi ini, peneliti juga menyelidiki benda-benda tertulis seperti peraturan-peraturan, materi ajar, serta data-data terkait yang dibutuhkan untuk 
mendukung dan menguatkan data yang sudah diperoleh melalui teknik pengambilan data yang lain.

Wawancara, dilakukan untuk memperoleh data dari subjek penelitian yaitu dari responden yang merupakan guru pengajar mata pelajaran Kejuruan Jurusan Teknik Kendaraan Ringan yang menggunakan model team teaching, pihak struktural sekolah yang terdiri dari kepala sekolah dan pihak Jurusan Teknik Kendaraan Ringan, dan juga dari siswa sebagai objek pembelajaran.

Teknik Analisis Data

Penelitian ini menggunakan analisis data induktif. Moleong (2000:103) menyatakan bahwa analisis data adalah proses mengorganisasikan dan mengurutkan data kedalam pola, dan kategori, serta satuan uraian dasar sehingga dapat ditemukan teama yang dapat dirumuskan. Menurut Miles dan Hubermen (1992:23) menjelaskan bahwa aktivitas dalam analisis data kualitatif dilakukan secara interaktif dan terus menerus pada setiap tahapan penelitian sampai tuntas dan datanya jenuh. Aktivitas dalam analisis data tersebut meliputi; data collection, data reduction, display data dan conclusion drawing verification. Hal ini dikenal dengan analisis interactive model.

\section{HASIL DAN PEMBAHASAN}

SMKN 1 Gombong melaksanakan model pembelajaran team teaching pada seluruh mata pelajaran kejuruan (produktif), baik untuk mata pelajaran teori kejuruan maupun praktik kejuruan. Pada saat pembelajaran mata pelajaran (mata diklat) kejuruan pada program keahlian Teknik Kendaraan Ringan, setiap tim mengajar terdiri dari dua orang guru. Kedua guru tersebut, salah satu merupakan guru pokok, sedangkan guru yang berikutnya merupakan guru pendamping. Pengertian guru pokok di sekolah tersebut, yaitu seorang guru mata pelajaran kejuruan yang mengampu suatu mata pelajaran kejuruan (produktif) tertentu dengan jumlah kelas yang diampu adalah seluruh kelas pada tingkat tersebut. Sedangkan guru pendamping, adalah guru di dalam tim mengajar yang tidak mengajar pada keseluruhan kelas pada tingkat tertentu.

Selain hal tersebut di atas, guru pokok juga merupakan guru yang diberikan tanggung jawab atas administrasi dan laporan hasil belajar pada suatu mata pelajaran produktif pada suatu tingkat (X, XI, atau XII). Guru, baik sebagai guru pokok maupun guru pendamping memiliki tugas dan tanggung jawab yang sama. Dalam pembelajaran teori kejuruan, guru pokok dan guru pendamping mengajar secara bergantian dalam memberikan penjelasan kepada siswa, meskipun demikian seluruh tim tetap berada di dalam ruang kelas.

Dengan demikian pelaksanaa team teaching di SMKN 1 Gombong relevan dengan konsep team teaching yang disampaikan Quinn dan Kanter (Laughlin, Nelson dan Donaldson, 2011:1) "Team teaching can be defined as a group of two or more teachers working together to plan, conduct, andevaluate the learning activities for the same group of learners. It is simply team work between two qualified instructors who, together, make presentations to an audience."

Selain konsep team teaching di atas, pelaksanaan team teaching di SMKN 1 Gombong relevan dengan Pedoman Pelaksanaan Tugas Guru dan Pengawas (Depdiknas, 2009), dijelaskan bahwa pembelajaran tim harus memenuhi prinsip-prinsip berikut: (1) Dilaksanakan apabila semua topik/pokok bahasan pada mata pelajaran tertentu memerlukan lebih dari satu orang guru untuk menangani satu rombongan belajar yang proses pembelajarannya merupakan satu kesatuan. (2) Perencanaan dalam pemilihan pokok bahasan dilakukan pada awal tahun ajaran. (3) Pembelajaran bertim dilaksanakan pada tiap minggu. (4) Jumlah guru bertim disesuaikan dengan karakteristik materi pembelajaran. (5) Anggota tim berasal dari guru-guru dari 
sekolah yang sama. (6) Perencanaan, pelaksanaan dan evaluasi harus dilakukan bersama-sama oleh anggota tim. (7) Setiap guru dalam pembelajaran bertim memiliki jumlah tatap muka yang sama sesuai dengan struktur kurikulum.

Dari sisi manajemen, pembelajaran team teaching di SMKN 1 Gombong telah direncanakan sejak awal tahun pembelajaran. Perencanaan tersebut meliputi pembagian tim, tugas dan tanggung jawab tim, jadwal mengajar, pembagian bengkel praktik kejuruan. Perencanaan dipimpin oleh ketua program keahlian dalam rapat awal tahun ajaran.

Dalam perencanaan itu sendiri, terdapat beberapa prinsip perencanaan yang baik, di antaranya yaitu: (1) Keadaan sekarang. (2) Keberhasilan dan faktorfaktor kritis keberhasilan. (3) Kegagalan masa lampau. (4) Potensi (5) Kemampuan merubah kelemahan menjadi kekuatan dan ancaman menjadi peluang (analisis SWOT). (6) Mengikutsertakan pihak terkait. (7) Memperhatikan komitmen dan mengkoordinasikan pihak terkait. (8) Mempertimbangkan keefektifan dan efisiensi, praktis, transparansi, realistis, legal. (9) Jika mungkin, uji coba kelayakan. Dari prinsip tersebut diketahui bahwa dalam proses perencanaan pembelajaran belum mencakup beberapa prinsip yang ada. Di antara prinsip yang belum dipenuhi adalah belum adanya analisis SWOT terkait pembelajaran itu sendiri maupun terkait guru yang menjalankan pembelajaran team teaching tersebut. Hal tersebut berdampak pada adanya proses yang cenderung sama dan stagnan dari tahun ke tahun, sehingga hasil yang diperolehpun relatif sama. Selain itu juga belum dipertimbangkan faktor kritis keberhasilan maupun kegagalan dalam pembelajaran sebelumnya.

Selanjutnya, seluruh guru yang telah dibagi ke dalam tim yang masing-masing terdiri dari dua orang guru melaksanakan pembelajaran team teaching sesuai dengan apa yang telah di tentukan pada rapat awal tahun ajaran. Pembelajaran dapat berjalan dengan baik melalui model pembelajaran team teaching tersebut. Namun demikian, proses pengawasan dan evaluasi belum berjalan maksimal. Meskipun telah terdapat jadwal dan orang yang bertugas untuk melakukan supervisi ataupun pengawasan, akan tetapi proses ini belum menyentuh pada pengawasan secara khusus dari pelaksanaan pembelajaran team teaching itu sendiri.

Meskipun sudah berjalan cukup baik, proses pembelajaran yang berlangsung dari tahun ke tahun cenderung sama tanpa adanya sebuah evaluasi yang mendalam terkait pelaksanaan team teaching secara khusus. Proses evaluasi ini dibutuhkan sebagai salah satu acuan dalam proses perencanaan selanjutnya.

Sementara itu, team teaching di SMKN 1 Puring Pembelajaran dengan menggunakan model tersebut dilakukan dengan membagi guru ke dalam tim, dengan masing-masing tim terdiri dari dua orang guru untuk mengampu suatu kompetensi keahlian pada mata pelajaran produktif, baik untuk praktik kejuruan maupun teori kejuruan. Pembagian tim ditentukan berdasarkan kompetensi yang dimiliki masing-masing guru yang sesuai dengan kompetensi atau mata pelajaran yang diberikan pada semester tersebut.

Tim yang terbentuk, merupakan satu tim mengajar yang memiliki tugas dan tanggung jawab yang sama. Pada tim tersebut tidak terdapat ketua tim ataupun anggota tim. Kedua guru tersebut merupakan satu tim yang sama-sama memiliki tanggung jawab atas seluruh kegiatan dan proses pembelajaran serta administrasi dan kelengkapan mengajar. Dalam pembelajaran, guru memiliki tugas yang sama dalam mengajar baik dalam praktik maupun teori.

Akan tetapi, dalam pelaksanaan pembelajaran team teaching di kelas, terdapat mata pelajaran yang memiliki kompetensi berbeda, akan tetapi dijadikan satu mata pelajaran dengan satu tim pengajar yang terdiri dari dua orang guru dengan kompetensi keahlian yang 
berbeda. Selain itu, terdapat pula pembelajaran team teaching di mana guru tidak mengajar secara bersama, akan tetapi hadir secara bergantian di dalam kelas pada saat mengajar teori kejuruan maupun praktik kejuruan sesuai pembagian yang disepakati bersama internal tim tersebut. Sehingga proses pembelajaran team teaching tidak berjalan maksimal sesuai dengan konsep team teaching yang seharusnya sebagaimana dijelaskan dalam konsep dasar team teaching bahwa; Team teaching can be defined as a group of two or more teachers working together to plan, conduct, and evaluate the learning activities for the same group of learners. It is simply team work between two qualified instructors who, together, make presentations to an audience. (Laughlin, Nelson dan Donaldson, 2011:3)

Dengan demikian, di dalam pembelajaran tidak akan diperoleh adanya; 1) berbagi kekuatan degan anggota timnya untuk membagikan secara merata jalan yang sama dengan kontrol bersama pada peserta didik. 2) mengobservasi orang pertama untuk saling menciptakan best practice (hasil terbaik). 3) menggali lebih dalam pengembangan kurikulum, perencanaan kebutuhan dan pengorganisasian material.

Dalam sisi manajemen, perencanaan team teaching pada dasarnya telah dilaksanakan pada tiap awal tahun ajaran, akan tetapi perencanaan yang dilakukan belum mencakup adanya perencaan tugas yang jelas pada masing-masing guru yang melaksanakan pembelajaran team teaching. Meskipun demikian, pembagian tim, dan jadwal telah ditentukan dan disepakati pada rapat awal tahun ajaran yang dipimpin oleh ketua program keahlian.

Perencanaan yang baik diharapkan mampu menerapkan prinsip-prinsip perencanaan yang baik, diantaranya: (1) Keadaan sekarang. (2) Keberhasilan dan faktor-faktor kritis keberhasilan. (3) Kegagalan masa lampa. (4) Potensi. (5) Kemampuan merubah kelemahan menjadi kekuatan dan ancaman menjadi peluang (analisis SWOT). (6) Mengikutsertakan pihak terkait. (7) Memperhatikan komitmen dan mengkoordinasikan pihak terkait. (8) Mempertimbangkan keefektifan dan efisiensi, praktis, transparansi, realistis, legal. (8) Jika mungkin, uji coba kelayakan.

Dari prinsip perencanaan tersebut di atas proses perencanaan pembelajaran team teaching yang telah dilaksanakan di SMKN 1 Puring belum mencakup seluruh prinsip tersebut. Hal yang cukup mendasar adalah belum dilaksanakananya analisis SWOT untuk pembelajaran selanjutnya dengan salah satu bahan pertimbangannya adalah hasil dari supervisi, maupun pengawasan dan evaluasi pembelajaran. Sehingga, pembelajaran yang ada cenderung sama. Selanjutnya, Dalam pelaksanaan pembelajaran team teaching tersebut, sebagaimana telah disebutkan sebelumnya, pembelajaran tersebut belum memenuhi prinsip pembelajaran team teaching dimana masing-masing guru memiliki tugas dan tanggung jawab yang sama serta hadir secara bersama dalam satu kelas yang sama untuk menyampaikan suatu kompetensi yang akan dicapai dengan model pelaksanaan pembelajaran team teaching yang disepakati bersama.

Melihat kondisi tersebut, dapat diketahui pula bahwa dalam pengorganisasian pembelajaran team teaching belum maksimal sehingga masing-masing guru melakukan tugas mengajar sesuai dengan kesepakatan bersama internal tim, dan bukan berdasarkan konsep team teaching yang disepakati dan dipahami bersama.

Selain hal tersebut, proses supervisi sangat dibutuhkan untuk mengontrol pelaksanaan pembelajaran team teaching. Namun demikian, proses ini belum berjalan maksimal sehingga proses evaluasi pelaksanaan selanjutnya pun belum berjalan optimal. Hal tersebut secara khusus terkait dengan evaluasi pembelajaran team teaching yang belum berjalan. Evaluasi ini menjadi bagian yang 
penting sebagai bahan pertimbnagan dalam menentukan langkah ataupun proses pembelajaran team teaching selanjutnya yang lebih efektif.

\section{PENUTUP}

\section{Simpulan}

Pembelajaran team teaching pada mata pelajaran kejuruan Program Keahlian Teknik Kendaraan Ringan di SMKN 1 Gombong telah berjalan dengan cukup baik. Team teaching di SMKN 1 Gombong dilaksanakan dengan melakukan pembagian guru ke dalam tim mengajar yang selanjutnya bertanggung jawab atas proses pembelajaran pada masing-masing mata pelajaran tersebut.

Pada setiap awal tahun ajaran baru maupun awal semester dilakukan perencanaan bersama untuk pembelajaran team teaching selanjutnya yang meliputi guru mata pelajaran apa yang akan diajarkan, tim yang akan mengajar, serta tugas masing-masing tim. Namun, dalam perencanaan tersebut, masih ada beberapa prinsip perencanaan yang belum terpenuhi.

Ketua jurusan (program Keahlian TKR) memimpin dan mengkoordinasikan guru untuk bersama-sama melakukan pembagian tugas serta tim dan mengatur pelaksanaan pembelajaran team teaching agar berjalan efektif.

Pembelajaran team teaching $\mathrm{di}$ SMKN 1 Gombong cenderung mengarah pada penerapan model pembelajaran team teaching tag teaching/traditional team teaching.

Kepala sekolah dan Ketua Program keahlian merupakan pihak yang bertanggung jawab atas proses evaluasi serta supervisi pembelajaran. Proses evaluasi pembelajaran team teaching belum berjalan dengan baik, akan tetapi baru sebatas pengawasan pada pembelajaran secara umum belum menyentuh pembelajaran team teaching secara khusus.

Gambaran pelaksanaan pembelajaran team teaching pada Program Keahlian Teknik Kendaraan Ringan di
SMKN 1 Puring belum memenuhi prinsip-prinsip pembelajaran bertim yang sesungguhnya. Pembagian tim yang dilakukan baru sebatas bertujuan untuk pemenuhan beban mengajar minimal guru 24 jam pembelajaran pada setiap minggunya. Team teaching di SMKN 1 Puring masih membutuhkan beberapa pengembangan dalam pelaksanaan masing-masing proses dalam tahapan manajemen di antaranya proses perencanaan. Masih dibutuhkan perencanaan yang lebih matang lagi terkait analisis SWOT kebutuhan pembelajaran selanjutnya agar tidak berjalan sama dari tahun ke tahun.

Ketua jurusan (Program Keahlian TKR) melakukan koordinasi pada setiap awal tahun maupun awal semester untuk melakukan pembagian tugas mengajar, pembagian tim, serta pembagian kelas dan mata pelajaran yang akan diampu. Akan tetapi, belum secara tegas dan rinci menjelaskan pembagian tugas guru pada saat pembelajaran team teaching berlangsung.

Pembelajaran team teaching yang dilaksanakan di SMKN 1 Puring belum menunjukkan adanya kejelasan konsep pembelajaran team teaching. Selain itu, belum ada satu model pembelajaran team teaching yang sesuai dengan apa yang dilaksanakan di SMKN 1 Puring. Kepala sekolah dan Ketua Program keahlian merupakan pihak yang seharusnya bertanggung jawab dalam proses supervisi serta evaluasi pembelajaran. Dengan demikian, akan selalu dapat diketahui perkembangan serta kekurangan dan kelebihan apa yang telah dimiliki sebagai pertimbangan proses selanjutnya.

Pada dasarnya supervisi telah diupayakan untuk dilaksanakan, akan tetapi belum berjalan dengan baik. Sehingga dari proses ini, proses evaluasi pembelajaran team teaching belum dapat berjalan dengan optimal.

\section{Saran}

Di SMKN 1 Gombong, masih dibutuhkan sebuah perencanaan yang 
lebih matang terkait prinsip-prinsip perencanaan dalam manajemen yang baik diantaranya diperlukan sebuah analisis SWOT sebagai bahan pertimbangan selanjutnya. Perencanaan ini dilakukan bersama antara ketua program keahlian dengan seluruh guru yang terlibat dalam pembelajaran team teaching. Selain itu, terkait supervisi yang dilakukan, diperlukan sebuah supervisi yang di dalamnya juga mencakup poin pelaksanaan pembelajaran bertim. Supervisi ini menjadi tanggung jawab kepala sekolah dan secara khusus menjadi tanggung jawab ketua program keahlian untuk menjalankan dan mengkoordinasikannya. Hal tersebut dibutuhkan karena hampir seluruh pembelajaran kejuruan dilakukan dengan model bertim.

Hal berikutnya yang perlu diperhatikan adalah perlu adanya sebuah pemahaman konsep team teaching yang lebih mendalam baik oleh ketua program keahlian dan lebih khusus lagi bagi guru. Dengan demikian, guru dapat mengaplikasikan berbagai model yang ada untuk dapat disesuaikan dengan kondisi peralatan, ruangan, maupun siswa, maupun target kompetensi yang akan diajarakan.

Sementara itu, bagi SMKN 1 Puring, Pada perencanaan, diperlukan sebuah perencanaan yang matang terkait berbagai hal yang menjadi prinsip perencanaan yang baik dalam sebuah manajemen. diperlukan pula adanya pemahaman yang sama tentang konsep pembelajaran team teaching yang sesungguhnya.

Pada tahap selanjutnya, dibutuhkan sebuah pengorganisasian yang baik. Dalam pengorganisasian tersebut dibutuhkan sebuah kejelasan tugas dan pembagian tim serta tugas di dalam tim yang baik. Selain itu juga dibutuhkan adanya pengarahan yang jelas tentang model pembelajaran team teaching yang sesungguhnya kepada seluruh guru.

Guru yang telah dibentuk di dalam sebuah tim mengajar, diharapkan memiliki pemahaman dan konsep yang sama tentang pembelajaran bertim yang akan dilaksanakan. Selain itu, diperlukan pula sebuah supervisi pembelajaran yang terkait pelaksanaan pembelajaran bertim yang dijalankan dengan baik.

\section{DAFTAR PUSTAKA}

Departemen Pendidikan Nasional (2009). Pedoman Pelaksanaan Tugas Guru Dan Pengawas. Jakarta: Dirjen Peningkatan Mutu Pendidik dan Tenaga Kependidiakan.

Marilyn, M, Alvis, M, Marilyn, W .(2005). Integrated coTeaching.http:// www.uft.org/ teaching/ integrated-co-teaching-ict, 10 des 2013, 10:05.

Laughlin, K, Nelson, P \& Donaldson, S (2011). Sucsessfully Applying Team Teaching with Adult Learners. Team Teaching, vol 40, Nov.1, 2011.

Miles, M.B \& Huberman, A.M (1992). Qualitative Data Analysis. London New Delhi: Sage Publication.

Moleong, Lexy J. (2000). Metodologi Penelitian Kualitatif. Bandung: Remaja Rosdakarya. 